1981

\title{
Self-Determination: An Important Dimension of the Demand for Freedom
}

Lung-chu Chen

New York Law School, lungchu.chen@nyls.edu

Follow this and additional works at: https://digitalcommons.nyls.edu/fac_articles_chapters

Part of the Human Rights Law Commons, International Law Commons, and the Law and Philosophy Commons

\section{Recommended Citation}

American Society of International Law Proceedings, Vol. 75, pp. 88-93

This Article is brought to you for free and open access by the Faculty Scholarship at DigitalCommons@NYLS. It has been accepted for inclusion in Articles \& Chapters by an authorized administrator of DigitalCommons@NYLS. 
would reaffirm the value aspect of our own system, he was accused by these same people of "softheadedness." This, for Professor FARER, was clinical schizophrenia.

Of course ideas were powerful instruments for subverting the enemy's forces and marshaling one's own. The Polish workers were plainly not motivated simply by the desire for more meat. A recent poll taken in Poland indicated that the workers were driven by an authentic, personally experienced passion for industrial democracy, indeed for a liberty in some respects more profound than the kind practiced in the United States.

Perhaps it was this confusion about the relationship between moral and strate. gic concerns which led Professor Fox to say a passing good word about "quiet diplomacy." Too open and aggressive advocacy of human rights, including its liberty dimension, would frighten those who saw altruism and self-interest in hopeless conflict. Professor FARER stated that however much he might object to this viewpoint, such objections were trivial compared to his difficulty with the supposed virtues of quiet diplomacy. Moreover, Professor FARER was not sure quiet diplomacy meant anything. Clearly it did not mean telling thugs privately that unless they took certain ameliorative steps they would find themselves subject to an array of sanctions. Rather, it was always offered as an alternative to concrete measures.

What no one ever bothered to suggest was on what theory of human causation should quiet diplomacy succeed. The only possible theory was that dictators and pretorian guards were on the whole stupid. They used far more heinous methods than their purposes required so they needed a little quiet advice from their friends. So advised, they would eliminate the gratuitous thumbscrews. Professor Faner believed this unlikely to occur. The unfortunate truth was that the most thuggish governments were not gratuitously sadistic. They appreciated better than their quiet advisors from abroad how to cap the volcanos they governed. Because they were prudent, they might throw their soft-spoken foreign friends a bone or two out of the thousands they had collected. For what was a bone or two if they kept the voices soft and capital and weapons flowing into the hands of the enemies of liberty?

Open and frank criticism by a still great and prestigious power, even when backed by the thin carrots and fragile sticks fretfully employed by the last administration, carried weight because human rights had become a vital ideology, and those exposed for violating them suffered in their own countries a frightening loss of legitimacy. This, was why they profoundly preferred an administration which professed an adherence to a policy of quiet diplomacy.

\section{Self-Determination: An Important Dimension OF THE DEMAND FOR FREEDOM}

\section{by Lung-chu Chen*}

In his profound and interesting paper, Professor Fox has presented some perspectives about self-determination of a historian and a political scientist. Since this is a gathering of international lawyers, I should like to make my remarks with an emphasis on a policy-oriented legal analysis.

As underscored in Professor Fox's paper, the demand for self-determination is

、 *Professor of Law, New York Law School. 
an important dimension of the demand for freedom in our contemporary world. It is the demand of human beings to form groups and to identify with groups that can best promote and maximize their pursuit of values both in individual and aggregate terms. This is the freedom for which our forefathers fought, and for which many people and groups are today fighting in different parts of the globe.

The new era of self-determination is symbolized by the contrasting fates of Biafra and Bangladesh. As former colonial peoples and territories substantially disappear, the focus of attention has shifted from colonial to noncolonial contexts in relation to claims of self-determination. The principle of self-determination has played a leading role in accelerating the emancipation of millions and millions of people from former colonial shackles. But as decolonization comes to an end, will the principle of self-determination be interred? Is it a doctrine with limited historical application or one with universal applicability?

Self-determination is an integral part of a more comprehensive social process in which groups and individuals, with varying patterns of demands, expectations, and identifications, employ strategies and resources, through institutions, to attain their goals.

The demands of humankind to secure an optimum freedom and wide sharing of power have been made under a variety of legalistic labels and contexts. Selfdetermination may be invoked singly or in combination with other labels such as sovereignty, independence, and nonintervention.

Comprehensively formulated, claims to self-determination can be divided into two basic categories:

1. Claims involving establishment of a new entity-that is, claims by a group within an established entity to form a new entity from part of the preexisting entity;

2. Claims not involving establishment of a new entity, notably:

a. Claims of an entity to be free of external coercion;

b. Claims of a people to overthrow their effective rulers and establish a new government in the whole of an entity (i.e., the right of revolution).

c. Claims of a group within an entity to such special protection as autonomy.

Our present focus relates primarily to the first category, namely, claims of a group within an established entity to form a new entity from part of a preexisting entity, and hence to establish and maintain its own internal decision processes and external relations.

The principle of self-determination had its origin in the 17th century when nation-states first emerged. It was deeply rooted in the concept of "nationality" at the time. The principle of "national self-determination" was crystallized at the end of World War I under the strong championship of President Woodrow Wilson. Because of its universal appeal rooted in the concept of human dignity and linked to the maintenance of world public order, the principle was enshrined in the Charter of the United Nations, as sustained by the systems of international trusteeship and nonself-governing territory.

Both the International Covenant on Civil and Political Rights and the International Covenant on Economic, Social, and Cultural Rights accord a prominent place to the principle of self-determination. In identical words, both Covenants proclaim in their first article that "All peoples have the right of self-determination. By virtue of that right they freely determine their political status and freely pursue their economic, social and cultural development." This principle has been affirmed and reaffirmed by the landmark Declaration on the Granting of Indepen- 
dence to Colonial Countries and Peoples (1960), the Declaration on Principles of International Law concerning Friendly Relations and Co-operation among States in accordance with the Charter of the United Nations (1970), and many other U.N. resolutions.

The impressive records of the United Nations in the task of facilitating independence for former trust territories and nonself-governing territories are indeed a matter of common knowledge. The application of the principle of self-determination in the colonial context has done so much to change today's world map, and to affect the world constitutive process of authoritative decision.

Without going into detail, I should like to highlight a few points from U.N. practice of the past 35 years in terms of "Who gets What, When, and How."

First, the question of "Who" is eligible for self-determination. The Charter stipulates "self-determination of peoples" and hence leaves the door wide open to arguments over "who" is entitled to self-determination-who constitutes a proper self-determining "unit." In ascertaining the basic unit of "nation" or "peoples" to exercise self-determination, the sociological, geographical, historical, psychological, and political factors of a social context have been recognized as relevant in U.N. practice. Thus, there is generally reference to the distinct features of the population concerned in terms of race, language, religion, or cultural heritage. It is also considered pertinent to discuss whether the territory involved is an identifiable territory or sufficiently contiguous to constitute one geographical unit. The wishes of the people-their demands, expectations, and identifications-are commonly conceded to have great weight.

After a provisional identification of "who" is entitled to self-determination, decisionmakers then face the problem of when and under what conditions selfdetermination is to be realized. In terms of timing, while the majority of member states favor self-determination for all dependent people without undue delay, they generally agree that cases differ too much from one another to warrant the adoption of "blanket" timing. Nevertheless, the overall pace of decolonization is indeed breathtaking.

In terms of method, the plebiscite has become a useful device. The importance of effective and impartial international supervision of every phase of the plebiscite process has clearly been demonstrated. Persuasion is indeed a desirable alternative to violence and coercion.

In terms of outcomes, although self-determination is commonly equated with "independence" it is not necessarily so. Arrangements other than independence, when freely chosen by the people concerned, are also acceptable. Viewed from U.N. practice and the context of world politics, self-determination does encompass alternatives ranging from considerable self-government inside an existing state, through an autonomous status within an established state, to complete independence. The fundamental requirement inherent in the concept of self-determination is a procedure, not a preset outcome. Whether the choice in a particular case is "independence" or otherwise is less important than whether it is genuinely and freely made by the people concerned. If the freedom of choice of the people is sustained, the policy objective of self-determination is fulfilled. The decisions of the United Nations manifest the flexibility that is realistically adapted to the contextual complexities of world affairs.

Viewing U.N. practice as a whole, it appears that the world community has as much interest as the people directly concerned in seeing that solutions to selfdetermination problems will be beneficial to all. Hence, in dealing with a claim to self-determination, the United Nations is concerned with: (1) the prospect of the 
territory or people concerned of becoming a viable state; (2) the present stage of advancement; and (3) the effect of granting or refusing the exercise of self-determination. It is considered essential that the people directly concerned have a reasonable prospect of becoming a viable entity-politically, economically, and so on-in this increasingly interdependent world.

The accelerating pace of decolonization in the post-World War II era has brought about the radical multiplication of many more smaller units-now called ministates-and caused a great deal of international concern about the viability of the existing ministates and the desirability of adding potential ministates. While no formula has been worked out to determine "how small is small" for the purposes of self-determination, the point that a new entity should be capable of developing itself as a viable entity and capable of acting responsibly in the external area is widely appreciated. For it is increasingly recognized that the very existence and function of a new entity have value consequences far beyond its own borders.

Will the experience gained from the past three and a half decades be relevant for the future? Will the experience gained from the accelerated independence of former trust territories and nonself-governing territories be relevant for the future? Will self-determination be relevant to the case of secession?

Yes, indeed! Self-determination is an ongoing process for people to forge and express their shared identity and destiny under ever-changing conditions.

The very essence of self-determination is the search for common identity and the unceasing effort of human beings to associate with fellow human beings in pursuit of the maximization of power, respect, and all the other values. It is a continuing search for a pattern of community life that is most likely to enhance the quality of life for all who are involved-in terms of security, shared respect, shared power and so on.

So long as social process moves on, human beings will not cease to search for both individual and group identities to make efforts to associate or disassociate with certain groups. Self-determination is not a one-shot affair. The attainment of independence from dependency does not foreclose human aspirations to search for appropriate group identification and affiliation in the defense and fulfillment of all important values.

Until the successful birth of Bangladesh as an independent state in 1971, it was widely assumed that in the contemporary world self-determination does not include the right of secession in the sense of a group breaking off from an established nation-state. The success of Bangladesh has significantly changed people's expectations.

Indeed, change is a cardinal principle in human affairs. Change occurs to groups as well as individuals. How demands for change for value fulfillment through group identification, association, and expression in the name of self-determination can be effected in a way to serve the common interest of the world community is a task of critical importance.

While the basic community policy of self-determination has been affirmed and reaffirmed, the key question remains: How to make its application relevant to particular instances to facilitate optimum achievement of the common interests, both minimum public order and optimum public order, minimum public order in the sense of the minimization of unauthorized coercion and optimum public order in the sense of the widest possible shaping and sharing of all values. It is indeed a pressing intellectual challenge.

In a decentralized world in which the effective power of state participants is 
patently discrepant decision in support of or in rejection of particular claims for self-determination will remain essentially decentralized, in the absence of effective collective decisions.

Hence, it is essential that appropriate criteria be articulated and formulated to guide and aid rational decisionmaking, unilateral or otherwise. Any serious review of a particular demand for self-determination from general community perspectives must require a careful contextual scrutiny, appraising systematically and rigorously many features of the particular context. To support or not to support a particular claim must depend upon the answers to many questions about each feature of the context, with the significance of any one feature being dependent upon the total configuration.

The test in granting or rejecting a demand for self-determination we recommend is not whether a given situation is "colonial" or "noncolonial," but whether granting or rejecting the demands of a group would move the situation closer to goal values of human dignity, considering in particular the aggregate value consiequences on the group directly concermed and the larger communities affected. In other words, the basic question is whether separation or unification would best promote security and facilitate effective shaping and sharing of power and of all the other values for most people. In a world of ever-increasing interdependence, a proper balance between freedom of choice and the viability of communities must be maintained.

It is essential to examine alternative consequences of either granting or rejecting claims for separation or unity. Specific consideration should be given to the following: (I) the degree to which the demanding group can form a viable entity, both in terms of its internal processes and its capacity to function responsibly in its relations with other entities; (2) the probable consequences of independence (separation) for the remaining people in the entity of which it has been a part; and (3) the consequences of demanded independence (separation) or unity (unification) for the aggregate pattern of value shaping and sharing for the peoples of the surrounding communities and for the world at large.

It is all these probable consequences that must be ascertained and tested in a given context by a careful analysis of contextual factors: participants, perspectives, situations, base values, strategies, outcomes, and effects.

Some of the more important points about relevant features may be briefly indicated.

In terms of perspectives, it is of the utmost importance to ascertain the intensity of demands in a population, observing the degree of support on the part of the elite and the rank and file, respectively. Identifications are of course crucial, especially the intensity and inclusivity of identification with a territorial community and the range and degree of identification with regional and global communities. Hence, it is vital to ascertain: (1) the degree to which the elite and the rank and file of the aspiring group identify with an existing or projected territorial community; (2) the extent to which members of the aspiring group associate themselves with all members of an existing or projected territorial community; (3) the degree to which members of the aspiring group identify with a single class or ethnic or lingusitic group; (4) the degree of territorial inclusivity; and (5) the range and degree of identificiation with regional and global communities and the degree of conformity to regional and global public policies. Another component is the matter-of-fact expectations about the past, present, and future entertained by the different participants. It is important to explore in which direction and to what extent alternative courses of action will affect these expectations. 
In terms of participation, attention should be directed to observation of how a particular group that makes a demand for separation fits in with the territorial and functional groups in the contemporary world, and to compare what changes in participation are being sought by demanders and by those who oppose the demand.

It is important to ask: Do the people concerned actively participate in making the demand? In the past what different choices were available to these people? What choices would be open to them in the future? Would granting the demand lead to significant value shaping and better distribution of values? Would participation in the relevant value processes be effectively widened?

Regarding situations, compare the present and proposed structures of authority, both functional and territorial, and ascertain the degree of sharing of a common destiny in reference to the larger community. Note the length of time over which previous factors have been integrated and consider alternative time intervals for future integration and consolidation.

With regard to base values, consideration should be given to consequences of accepting or denying a particular demand in terms of values. What are the present distributions of values of different groups? What changes are demanded in terms of authority and controlling values? What are the available alternatives and then consequences for people, territory, institutions, and resources?

In terms of viability of a political community, inquiry can be directed in terms of consideration for security, power, wealth, and other values.

The most important of all these features is of course the outcomes in terms of impact upon different values expected to attend each option, for the aspiring group, the old entity to which the aspiring group belongs, and the larger surround. ing communities, including the global community. Hence, the critical test in considering a claim to self-determination is to evaluate the aggregate value consequences for all those communities, potential as well as existing, in honoring or rejecting the claim, and to honor the option that will promote the largest net aggregate of common interest by fully estimating the relative costs and benefits of the different options for each of those communities.

While the trend of past decisions indicates that the United Nations, in dealing with issues relating to self-determination, stresses the basic distinction of colonial and noncolonial issues, this distinction need not be conclusive, particularly when colonialism is narrowly understood to be the domination by whites over nonwhites. The essence of self-determination is human dignity and human rights. Underlying the concept of human dignity is the insistent demand of the individual to form groups and to identify with groups that can best promote and maximize the pursuit of values both in individual and aggregate terms. The formation and reformation of groups are ongoing processes.

Legal doctrines operate in pairs of complementarity, here exemplified by the interplay between self-determination and territorial integrity. Is the seeming conflict between "territorial integrity" and self-determination irreconcilable? Territorial integrity for what?

It has increasingly become apparent that the absolute adherence to territorial integrity is no virtue-rather, it is self-defeating-when the people who demand freedom are subject to systematic deprivations on a vast scale. The principle of territorial integrity must not serve as a shield for tyrants, dictators, or totalitarian rulers; it must not become a screen behind which human deprivations are justified, condoned, and perpetuated. Today the world is too interdependent, humankind is living too closely together, to permit the doctrines of domestic juris- 